\title{
Rheological Characterization of Isabgol Husk, Gum Katira Hydrocolloids, and Their Blends
}

\author{
Vipin Kumar Sharma, ${ }^{1}$ Bhaskar Mazumder, ${ }^{2}$ and Vinod Nautiyal ${ }^{1}$ \\ ${ }^{1}$ Department of Pharmaceutical Sciences, Faculty of Medical Science \& Health, Gurukul Kangri University, Haridwar, \\ Uttarakhand 249404, India \\ ${ }^{2}$ Department of Pharmaceutical Sciences, Dibrugarh University, Dibrugarh, Assam 786004, India
}

Correspondence should be addressed to Vipin Kumar Sharma; vipin@gkv.ac.in

Received 31 January 2014; Revised 6 June 2014; Accepted 20 July 2014; Published 25 August 2014

Academic Editor: Melvin Pascall

Copyright (C) 2014 Vipin Kumar Sharma et al. This is an open access article distributed under the Creative Commons Attribution License, which permits unrestricted use, distribution, and reproduction in any medium, provided the original work is properly cited.

\begin{abstract}
The rheological parameters of Isabgol husk, gum katira, and their blends were determined in different media such as distilled water, $0.1 \mathrm{~N} \mathrm{HCl}$, and phosphate buffer ( $\mathrm{pH}$ 7.4). The blend properties of Isabgol husk and gum katira were measured for four different percentage compositions in order to understand their compatibility in dispersion form such as $00: 100,25: 50,50: 50$, $75: 25$, and $100: 00$ in the gel strength of 1 mass $\%$. The miscibility of blends was determined by calculating Isabgol husk-gum katira interaction parameters by Krigbaum and Wall equation. Other rheological properties were analyzed by Bingham, Power, Casson, Casson chocolate, and IPC paste analysis. The study revealed that the power flow index " $p$ " was less than " 1 " in all concentrations of Isabgol husk, gum katira, and their blends dispersions indicating the shear-thinning (pseudoplastic) behavior. All blends followed pseudoplastic behavior at thermal conditions as $298.15,313.15$, and $333.15^{\circ} \mathrm{K}$ and in dispersion media such as distilled water, $0.1 \mathrm{~N}$ $\mathrm{HCl}$, and phosphate buffer ( $\mathrm{pH}$ 7.4). Moreover, the study indicated the applicability of these blends in the development of drug delivery systems and in industries, for example, ice-cream, paste, nutraceutical, and so forth.
\end{abstract}

\section{Introduction}

Gums and mucilages are widely used natural materials for food and pharmaceutical industries. The natural materials have advantages over synthetic ones since they are chemically inert, nontoxic, less expensive, biodegradable, and widely available [1]. These can also be modified in different ways to obtain tailor-made materials and thus can compete with the available synthetic polymers. The importance of biocompatible and biodegradable hydrophilic polymers has wide applications in different fields such as polymer engineering, chemical engineering, pharmaceuticals, food, and agriculture because of their propensity to combine with others [2-4]. The blends of these biopolymers are also of significant importance and recently have been investigated for application in drug delivery systems and in the field of foods science $[5,6]$. In the plastic industry, polyvinyl alcohol blends with agar and hydroxyethylcellulose have been investigated in order to improve the mechanical properties of biodegradable films [5].
Such blends showed superior performances over the conventional individual polymers and, consequently, the range of applications have grown rapidly for such class of materials. In the recent years, carbohydrate and biodegradable polymers have been extensively used to develop the controlled release formulations of drugs having short plasma life. Amongst the various polymers employed, hydrophilic biopolymers are quite suitable because they are nontoxic and acceptable by the regulatory authorities [7]. The application of any natural gum or mucilage depends upon its viscosity. The choice of selecting the natural gum and its blends for sustained release effect depends upon its gelling strength [8]. The interacting blends of poly(acrylic acid) with poly(vinylpyrrolidone) or poly(vinyl alcohol) in aqueous solutions have been studied by ultrasonic, rheological, and viscometric techniques $[9$, 10]. Different types of interactions, such as electrostatic interaction, hydrogen bonding, and hydrophobic interaction, are established between biopolymers. In order to clarify the association of biopolymers through structure formation, it 
is important to study the molecular interactions of different kinds of biopolymers. It is thought that the structural formation of biopolymer blends is an important subject from both industrial and scientific points of view.

Isabgol husk is medicinally important polysaccharide and it has been reported for the treatment of constipation, diabetes, diarrhoea, inflammation bowl diseases, ulcerative colitis, cancer, obesity, high cholesterol, and so forth [11]. Husk mucilage obtained from the seed coat by mechanical milling/grinding of the outer layer of the seeds is fibrous and hydrophilic and forms the clear, colorless mucilaginous gel by absorbing water. Recently, the US Food and Drug Administration has authorized the use of food products containing soluble fiber from Isabgol husk [12]. A gastroretentive sustained release delivery system of ofloxacin has been developed with release polymers like psyllium husk and a swelling agent, crospovidone $[13,14]$.

Gum katira, an exudate from the bark of Cochlospermum religiosum (family Cochlospermaceae), is pale and semitransparent and insoluble in water but swells into a pasty transparent mass with water. It has obtained great importance in recent years and is exported annually from India for use in cigar, paste, and ice-cream industries [15]. The gum is sweet, thermogenic, anodyne, sedative, and useful in cough, diarrhea, dysentery, pharyngitis, gonorrhoea, syphilis, and trachoma [16]. It consists of equimolecular proportion of Lrhamnose, D-galactose, and D-galacturonic acid, together with traces of a ketohexose. It has been reported that $[1 \rightarrow 2]$ 4-linked galacturonic acid is present in the linear chain of this polysaccharide with similar residues of neutral sugars $[17,18]$.

This study has been carried out for rheological properties of blends comprising Isabgol husk and gum katira and is based on assessment of miscibility of Isabgol husk and gum katira blends in different concentrations. The effect of different thermal conditions was analyzed on blends miscibility and rheological characteristics.

\section{Materials and Methods}

Isabgol husk and gum katira were procured from local market. Other chemicals and regents such as potassium dihydrogen phosphate, sodium hydroxide, and hydrochloric acid of analytical grade were procured from Loba Chemie, Mumbai, and used as such without further purification and modification.

2.1. Preparation of Isabgol Husk and Gum Katira Dispersions. About 1 and 2 mass\% dispersion of Isabgol husk and gum katira were prepared in distilled water and kept aside at room temperature for $6 \mathrm{~h}$ to remove the entrapped air and complete swelling. The blends of Isabgol husk and gum katira comprising each 1 mass $\%$ were prepared by thoroughly mixing the above dispersions in three percentage ratios such as $75: 25,50: 50$, and $25: 75$, respectively. The blends by applying 2 mass\% of Isabgol husk and 1 mass\% of gum katira dispersion and vice versa were also prepared in the above compositions for assessing the effect of polysaccharides concentrations on miscibility. Viscosities of these dispersions in pure and blend form were determined in triplicate $(n=3)$ by Brookfield's viscometer (Model: RV DV-E, USA) by taking $6.7 \mathrm{~mL}$ of the sample into a removable sample chamber. The removable sample chamber was inserted into the water jacket assembly and an insulation cap was placed on the chamber to maintain the temperature constant of dispersions samples during measurements. For rheological investigation, spindle-18 (SC-18) was selected to perform the study. The compatibility in terms of miscibility of Isabgol husk and gum katira in blends containing different strengths of these polysaccharides was analyzed at $298.15,313.15$, and $333.15^{\circ} \mathrm{K}$.

2.2. Determination of Miscibility of Isabgol Husk-Gum Katira Blends. The miscibility of Isabgol husk and gum katira blends in dispersion form was studied by calculating the polymerpolymer interaction parameter " $\Delta b$ " of the blends using the Krigbaum and Wall equation [19]

$$
b_{m}=x_{1}^{2} b_{11}+2 x_{1} x_{2} b_{12}+x_{2}^{2} b_{22}
$$

where " $x_{1}$ " and " $x_{2}$ " are the mass fraction of Isabgol husk and gum katira, respectively, " $b_{11}$ " and " $b_{22}$ " are the respective interaction parameters of Isabgol husk and gum katira dispersions, respectively, " $b_{12}$ " is the interaction parameter of the blend system, and " $b_{m}$ " represents the global interaction between two polymeric species, respectively. Here, the interaction parameters " $b_{11}$ ", " $b_{22}$ ", and " $b_{m}$ " were calculated from the slope of the plot of reduced viscosity of Isabgol husk and gum katira and their blends versus concentration, respectively [20]. The samples were studied in triplicate $(n=3)$ and the data were represented as the mean of the successive results with their respective standard deviations. The linear relationship found from such plots for the entire composition is generally the characteristic of blend compatibility.

The miscibility of these blends was also analyzed by

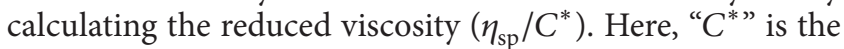
concentration of individual polysaccharide in blends and alone. Then, from the nature of the plot of $\left(\eta_{\mathrm{sp}} / C^{*}\right)$ versus $C^{*}$, blend compatibility was predicted. The values of intrinsic viscosity " $[\eta]_{m}$ " were calculated for both the individual polymers and their blends followed by extrapolation of " $\eta_{\mathrm{sp}} / C^{* \text { " }}$ to zero concentration [21]. The values of the intrinsic viscosity " $[\eta]_{m}$ " obtained from such plots for the blends were also calculated theoretically by using the following expression, and compared

$$
[\eta]_{m}=[\eta]_{1} x_{1}+[\eta]_{2} x_{2}
$$

The interaction parameter " $b_{12}^{*}$ " was calculated theoretically by using the equation

$$
b_{12}^{*}=\left(b_{1} b_{2}\right)^{1 / 2} \text {. }
$$

Here, the value of " $b_{1} b_{2}$ " was the slope of the plots of reduced viscosity versus concentration of the individual polymers calculated by using classical Huggins equation [20]:

$$
\frac{\eta_{\mathrm{sp}}}{C^{*}}=[\eta]_{0}+b C^{*} \text {. }
$$


Thus, the difference " $\Delta b$ " between the theoretically calculated " $b_{12}^{*}$ " from the above equation and that of the experimental " $b_{12}$ " calculated from the equation was calculated as

$$
\Delta b=\left(b_{12}-b_{12}^{*}\right) \text {. }
$$

2.3. Determination of Rheological Behaviour of Blends by Rheological Models. The analysis of rheological data obtained through investigation was treated by following mathematical models [21]. Non-Newtonian behavior can be simply expressed through an equation and in some cases; the coefficients of a model can be used to draw the inference regarding the performance of a fluid under conditions of use. Newtonian flow is defined by a phenomenon of response in shear stress for a change in shear rate (linear relationship). NonNewtonian fluids exhibit a nonlinear stress/rate relationship. The Newtonian equation for viscosity has been modified many times to characterize non-Newtonian behavior. Some of the widely used equations include the following:

Casson equation:

$$
\sqrt{\tau}=\sqrt{\tau_{0}}+\sqrt{\eta D}
$$

Casson chocolate equation:

$$
(1+a) \sqrt{\tau}=2 \sqrt{\tau_{0}}+(1+a) \sqrt{\eta} D,
$$

Bingham plastic equation:

$$
\tau=\tau_{0}+\eta D
$$

Power law:

$$
\tau=k D^{\eta},
$$

IPC paste analysis:

$$
\eta=k R^{s}
$$

where " $\tau$ " is shear stress $\left(\mathrm{N} / \mathrm{m}^{2}\right)$, " $\tau_{0}$ " yield stress/shear stress at zero shear rate $\left(\mathrm{N} / \mathrm{m}^{2}\right)$, " $D$ " is shear rate $\left(\mathrm{sec}^{-1}\right)$, " $a$ " is spindle radius, " $K$ " is consistency index ( $\mathrm{mPa} \cdot \mathrm{s})$, " $n$ " is flow index, " $\beta$ ", is consistency multiplier, " $R$ " is rotational speed $\left(\sec ^{-1}\right)$, and " $s$ " is shear sensitivity factor, respectively.

Using the magnitudes of " $K$ " and " $n$ ", apparent viscosity $\left(\eta_{\text {app }}\right)$ at shear rate of $1 \mathrm{sec}^{-1}(60 \mathrm{rpm})$ was calculated. In addition, the effect of temperature $\left(298.15,313.15\right.$, and $\left.333.15^{\circ} \mathrm{K}\right)$ on $\eta_{\text {app, } 60 \mathrm{rpm}}$ was studied for Isabgol husk, gum katira, and their blends dispersions using the Arrhenius equation [21]:

$$
\eta_{\mathrm{app}, 60}=A \exp \left(\frac{E_{\mathrm{act}}}{R T}\right)
$$

where $\eta_{\text {app,60 }} \mathrm{rpm}$ is the apparent viscosity (mPa.s) at $60 \mathrm{rpm}$ $\left(1 \mathrm{~s}^{-1}\right)$, “ $A$ " is a constant (mPa.s), " $T$ " is the absolute temperature $\left({ }^{\circ} \mathrm{K}\right)$, " $R$ " is the gas constant $\left(8.3144 \mathrm{~J} / \mathrm{mol}^{\circ} \mathrm{K}\right)$, and “ $E_{\mathrm{act}}$ " is the activation energy $(\mathrm{kJ} / \mathrm{mol})$, respectively.

The following equations were applied for the calculation of viscosity of blends from the individual viscosity data and from the volume of gum katira and Isabgol husk applied in the blends preparation. The rheological data obtained from individual polymeric dispersion of gum katira and Isabgol husk was compared with blends:

$$
\begin{gathered}
\eta=\eta_{1} \phi_{1}+\eta_{2} \phi_{2}, \\
\eta_{\text {mix }}=\eta_{2}+\frac{\phi_{1}}{\left(1 / \eta_{1}\right)-\eta_{2}+\left(\phi_{2} / 2 \eta_{2}\right)}, \\
\eta_{\text {mix }}=\eta_{1}+\frac{\phi_{2}}{\left(1 / \eta_{2}\right)-\eta_{1}+\left(\phi_{1} / 2 \eta_{1}\right)},
\end{gathered}
$$

where " $\eta_{1}$ " is the viscosity of Isabgol husk dispersion, " $\eta_{2}$ " the viscosity of gum katira dispersion, " $\phi_{1}$ " the volume fraction of Isabgol husk dispersion, and " $\phi_{2}$ " is the volume fraction of gum katira dispersion, respectively.

2.4. Statistical Analysis. The results of different parameters studied were treated statistically and the data were reported as mean \pm standard deviation (SD) for three successive determinations $(n=3)$. Statistical analysis was performed by Student's $t$-test, ANOVA, and $F$ test at 95\% confidence level, using a statistical package (SigmaStat v.2.07, Systat Software Inc., San Jose, California).

\section{Results and Discussion}

3.1. Determination of Viscosity and Shear Stress of Isabgol Husk and Gum Katira Blends. In order to understand the flow behaviour of the dispersions before and after blending, the dependence of flow properties like viscosity, shear stress, and shear rate was also investigated. The composition of blends of gum katira and Isabgol husk with their rheoparameters is shown in Table 1. The study was performed in triplicate $(n=3)$ and the data were represented as mean with standard deviation. As the flow behaviour of hydrophilic dispersion depends upon speed of rotation (shear rate), all these parameters were analyzed at a particular speed $(60 \mathrm{rpm}$ or $1 \mathrm{sec}^{-1}$ ) by maintaining the recommended rate of torque value. It was observed that, on increasing the concentration of Isabgol husk in blends, the viscosity was increased while a reverse effect was observed with gum katira dispersions. The impact of Isabgol husk on enhancement of viscosity of blends was considered due to its more water retention capacity as the values of viscosity of Isabgol husk and gum katira dispersion in $1 \% \mathrm{w} / \mathrm{v}$ dispersion were $137.6 \pm 1.3531 \mathrm{mPa}$ and $53.3 \pm$ $2.6147 \mathrm{mPa}$, respectively, at $298.15^{\circ} \mathrm{K}$. In all the dispersions, the viscosity of the blends was decreased on increasing the temperature from $298.15^{\circ} \mathrm{K}$ to $333.15^{\circ} \mathrm{K}$. The change in viscosity was slightly less on increasing temperature from $298.15^{\circ} \mathrm{K}$ to $313.15^{\circ} \mathrm{K}$ but these changes in viscosity were predicted more significant on increasing the temperature up to $333.15^{\circ} \mathrm{K}$ $(P<0.05)$. All the hydrocolloids comprising polysaccharides interact with water, reducing its diffusion and stabilizing its presence, and water is retained specifically through direct hydrogen bonding or the structure of these polymers contains water within extensive inter- and intramolecular voids. As the interactions between hydrocolloids and water depend 
TABLE 1: Viscosity and shear stress of Isabgol husk, gum katira, and their blends having 1:1 mass\% of Isabgol husk and gum katira on $298.15^{\circ} \mathrm{K}, 313.15^{\circ} \mathrm{K}$, and $333.15^{\circ} \mathrm{K}$ at $60 \mathrm{rpm}\left(1 \mathrm{sec}^{-1}\right)$.

\begin{tabular}{lcc}
\hline $\begin{array}{l}\text { Composition of } \\
\text { Isabgol husk and } \\
\text { gum katira }\end{array}$ & $\begin{array}{c}\text { Viscosity }(\mathrm{mPa}) \\
(\text { mean } \pm \mathrm{SD})^{*}\end{array}$ & $\begin{array}{c}\text { Shear stress }\left(\mathrm{N} / \mathrm{m}^{2}\right) \\
(\text { mean } \pm \mathrm{SD})\end{array}$ \\
\hline $\begin{array}{l}\text { At } 298.15^{\circ} \mathrm{K} \\
100: 0\end{array}$ & $137.6 \pm 1.3531$ & $1496.75 \pm 1.6833$ \\
$75: 25$ & $98.5 \pm 1.5527$ & $1301.85 \pm 4.2933$ \\
$50: 50$ & $88.6 \pm 2.4682$ & $1089.23 \pm 3.9310$ \\
$25: 75$ & $75.5 \pm 3.6669$ & $720.55 \pm 2.6253$ \\
$0: 100$ & $53.3 \pm 2.6147$ & $510.26 \pm 4.5279$ \\
At $313.15^{\circ} \mathrm{K}$ & & \\
$100: 0$ & $114.3 \pm 3.5369$ & $1244.58 \pm 3.8743$ \\
$75: 25$ & $92.9 \pm 1.3917$ & $1001.85 \pm 4.6793$ \\
$50: 50$ & $83.7 \pm 1.2326$ & $951.54 \pm 5.6126$ \\
$25: 75$ & $64.5 \pm 3.1119$ & $669.62 \pm 5.8796$ \\
$0: 100$ & $40.1 \pm 1.5991$ & $439.02 \pm 3.1245$ \\
At $333.15^{\circ} \mathrm{K}$ & & \\
$100: 0$ & $106 \pm 2.7203$ & $908.65 \pm 2.8533$ \\
$75: 25$ & $63.5 \pm 3.4664$ & $654.55 \pm 5.4932$ \\
$50: 50$ & $48.8 \pm 1.9902$ & $558.73 \pm 4.6455$ \\
$25: 75$ & $29.3 \pm 0.6741$ & $338.95 \pm 3.0102$ \\
$0: 100$ & $27.2 \pm 2.1417$ & $209.04 \pm 3.1193$ \\
\hline${ }^{*}$ Average of three successive results $(n=3), \mathrm{S} . \mathrm{D}$ is the standard deviation.
\end{tabular}

on hydrogen bonding, the thermal conditions influence the water retention capacity. Hence, on higher temperature, the retained water may come out from blends and results in lower viscosity. Also, the hydrocolloids retain their extended structures and give rise to mixed entanglement. These entanglements in blends of Isabgol husk and gum katira at higher concentration of Isabgol husk may lead to enhancement of viscosity. Moreover, large and conformationally stiff blends at higher concentration of Isabgol husk may present essentially static surfaces encouraging extensive structure in surrounding water and holding it for prolonged time.

\subsection{Effect of Acidic and Basic Media on Rheological Behaviour} of Isabgol Husk and Gum Katira. Isabgol husk and gum katira being polysaccharide in nature are composed of different pentose and hexose branched chain structures with terminal hydrophilic groups and these are responsible for water retention as well as interaction with various ionic dispersing media. Moreover, the manufacturing conditions during their applicability in various processes may also have an impact on their flow characteristics. Hence, the effect of acidic $(0.1 \mathrm{~N} \mathrm{HCl})$ and basic media (phosphate buffer $\mathrm{pH}$ 7.4) was analyzed on the flow pattern of $1 \% \mathrm{w} / \mathrm{v}$ aqueous dispersion of Isabgol husk and gum katira that are shown in Figure 1. The behaviour of husk and gum katira in $0.1 \mathrm{~N} \mathrm{HCl}$, phosphate buffer ( $\mathrm{pH} 7.4)$ and water was pseudoplastic in nature $(n<1)$ but the pattern of shear stress at different shear rates in these media was statistically different $(P<0.05)$.
The viscosity of Isabgol husk dispersion at $60 \mathrm{rpm}$ in distilled water was higher than in $0.1 \mathrm{~N} \mathrm{HCl}$ and phosphate buffer $(\mathrm{pH}$ 7.4) and the viscosities in these media were found to be 137.6 \pm $1.3531,76.2 \pm 0.458$, and $17.8 \pm 0.488 \mathrm{mPa}$, respectively. The remarkable viscosity in distilled water may be due to water retention in branched chain structure of polysaccharides. The presence of acidic content in the form of galacturonic acid may interact with acidic media causing change in branched chain network and results in slow penetration of acidic dispersing media in polysaccharide structure. The phosphate buffer may have ionic effect and cause defragmentation of chains configuration of husk polysaccharides. The reported study has shown that, by enzymatic modification, the gelling hardness and adhesiveness of Isabgol husk can be reduced as high as $23 \%$ in convention enzymatic treatment and from $48 \%$ to $55 \%$ in solid-state enzymatic procedure, respectively [21-23]. The gel hardness and adhesiveness reduction of acid modified samples of Isabgol husk under reaction temperatures of $25^{\circ} \mathrm{C}$ and $37.5^{\circ} \mathrm{C}$ have also been found to be similar to solid-state enzymatic modification of Isabgol husk dispersion [4]. In the present study, the reduction in gel hardness and adhesiveness was thought to be due to $\mathrm{HCl}$ under $25^{\circ} \mathrm{C}$ and $37.5^{\circ} \mathrm{C}$ having comparable ability with enzymes such as Viscozyme L of breaking polysaccharide molecule networks. In the reported study, the sharp decrease in both hardness and adhesiveness of acid treated Isabgol husk at $50^{\circ} \mathrm{C}$ was analyzed due to the stronger reaction between $\mathrm{HCl}$ and Isabgol husk which altered the molecular structure of Isabgol husk and inhibited the formation of junction zones [24]. The rheological behaviour of $1 \% \mathrm{w} / \mathrm{v}$ gum katira was also different in acidic and basic conditions and the flow patterns were different from Isabgol husk in these media $(P<0.05)$.

\subsection{Determination of Miscibility of Isabgol Husk and Gum} Katira Blends. According to Flory-Huggins [19], the free energy of mixing can be broken into two parts: an entropy part that always favors mixing and an enthalpy part that can either facilitate or prevent mixing, and it depends on the nature and intensity of the interaction between the two components. At a given temperature, complete, partial, or zero miscibility can be obtained with attractive (FloryHuggins interaction parameter $\chi \leq 0$ ), weak repulsive $(\chi>0)$, or strong repulsive $(\chi \gg 0)$ interactions, respectively. Here, miscibility is the equilibrium composition of the two components above which the free energy of mixing is greater than zero, and phase separation is thermodynamically favorable. Generally, the immiscible blends of polymers show a negative deviation $(\Delta b<0)$ as per (1) and (5) due to the heterogeneous nature of the components and results in phase separation, whereas positive deviation $(\Delta b>0)$ is expected for the blends of comparatively higher solubility and homogeneous nature of the components [25]. The comparative analysis of experimental viscosity determination of different blends containing 1 mass\% of Isabgol husk and 1 mass $\%$ of gum katira with mathematical analysis by (12), (13), and (14) has been shown in Figure 2. The viscosity determined by mathematical expressions and experimentations was similar and no significant difference $(P>0.05)$ was observed. The 


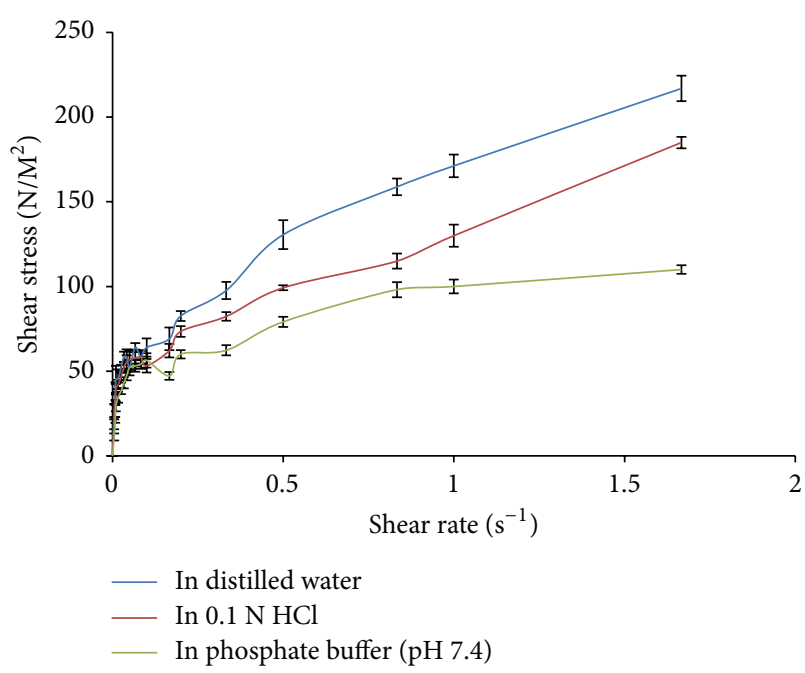

(a)

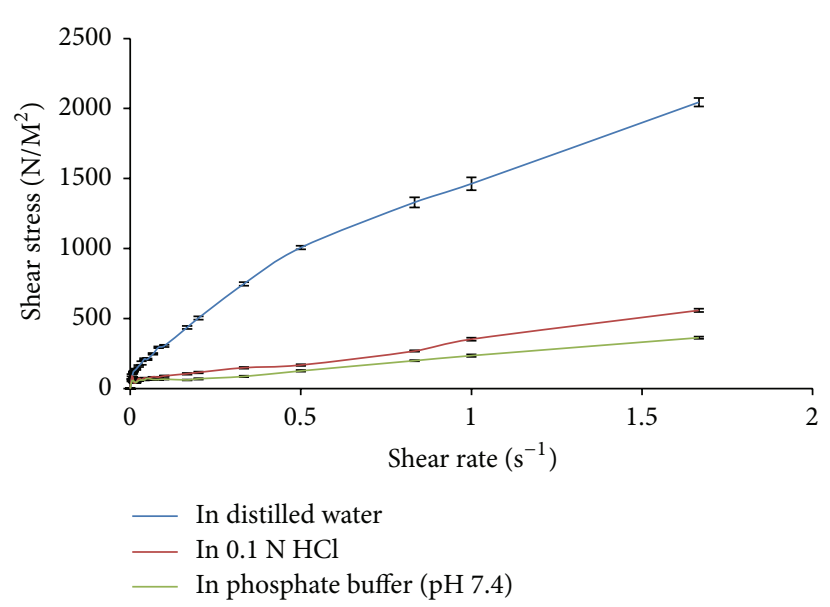

(b)

FIGURE 1: Flow behaviour of $1 \%$ w/v gum katira (a) and Isabgol husk (b) in distilled water, $0.1 \mathrm{~N} \mathrm{HCl}$, and phosphate buffer (pH 7.4) (the data used in the graph is the mean of three successive results $(n=3)$ and shown with error bars of SD).

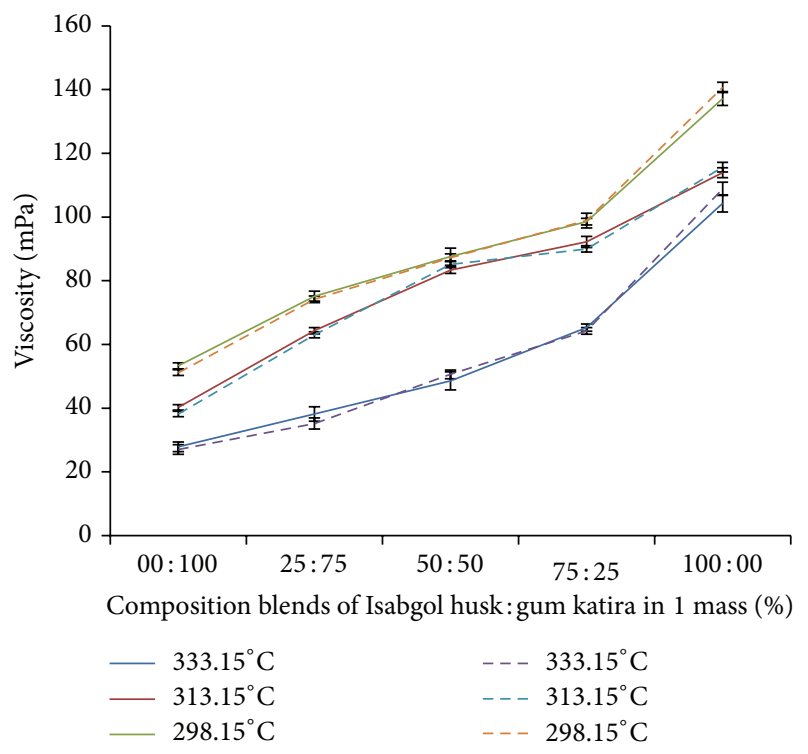

FIGURE 2: Comparative viscosity of blends determined experimentally (-) and by mathematical expressions $(\cdots)$ at $298.15^{\circ} \mathrm{K}$, $313.15^{\circ} \mathrm{K}$, and $333.15^{\circ} \mathrm{K}$ (the data used in the graph is the mean of three successive results $(n=3)$ and shown with error bars of SD).

calculated values of " $\Delta b$ " for blends at 1 mass\% of Isabgol husk and $1 \mathrm{mass} \%$ of gum katira with interaction parameter " $b_{12}$ " calculated theoretically by (3), (4), and (5) and experimentally are represented in Table 2. It was observed that the values of " $\Delta b$ " were increased on increasing the temperature from room temperature to $313.15^{\circ} \mathrm{K}$ and to $333.15^{\circ} \mathrm{K}$, respectively, in all compositions of blends, and, at higher concentrations of Isabgol husk in blends $(2: 1)$, " $\Delta b$ " was found to be 42.64 at $298.15^{\circ} \mathrm{K}$ and 11.78 at $333.15^{\circ} \mathrm{K}$, respectively. However, in blends comprising higher concentrations of gum katira $(1: 2)$,
" $\Delta b$ " was 7.7 at $298.15^{\circ} \mathrm{K}$ and 3.69 at $333.15^{\circ} \mathrm{K}$, respectively. These data of interaction parameter " $\Delta b$ " indicated the interaction and miscibility of blends at experimental thermal conditions and compositions of Isabgol husk and gum katira such as $1: 1,2: 1$, and $1: 2$ in mass\% while more interaction and miscibility were depicted in blends containing comparatively higher Isabgol husk concentrations. The intrinsic viscosities of blends having polymer ratio $1: 1$ mass $\%$ at $298.15^{\circ} \mathrm{K}$, $313.15^{\circ} \mathrm{K}$, and $333.15^{\circ} \mathrm{K}$ were found to be $9.11 \pm 1.0613$, $20.786 \pm 0.6932$, and $29.885 \pm 2.0232 \mathrm{mPa} \cdot \mathrm{s}$, respectively. The values of intrinsic viscosities of blends at 2:1 mass\% (Isabgol husk: gum katira) were found to be $23.92 \pm 1.210$, $65.571 \pm 2.6932$, and $79.143 \pm 1.8001 \mathrm{mPa} \cdot \mathrm{s}$ at $298.15^{\circ} \mathrm{K}$, $313.15^{\circ} \mathrm{K}$, and $333.15^{\circ} \mathrm{K}$, respectively. But, on increasing gum strength in blends as 2 mass\%, the intrinsic viscosity was found lower than that obtained in higher strength of Isabgol husk. The results were $14 \pm 2.0513,27.179 \pm 0.8562$, and $49.286 \pm 2.6320 \mathrm{mPa} \cdot \mathrm{s}$ at $298.15^{\circ} \mathrm{K}, 313.15^{\circ} \mathrm{K}$, and $333.15^{\circ} \mathrm{K}$, respectively. The experimental data of intrinsic viscosities was similar to mathematical results obtained by $(2)(P>0.05)$.

\subsection{Effect of Thermal Conditions on Consistency Index (K) and} Flow Index (n) of Isabgol Husk-Gum Katira Blends. The flow behaviour of Isabgol husk-gum katira blends (1:1 mass\%) indicated Newtonian flow pattern (e.g., viscosity was constant with increment of shear rate) at lower shear rate regions, while a shear-thinning flow behavior (e.g., viscosity decreased with increment of shear rate) was observed at higher shear rate regions. It seems that, at lower shear rates, there could be a constant formation and disruption of chain-chain entanglements and the rate of disruption with formation of the polymer chain entanglements could be at equilibrium; therefore, the viscosity might remain unchanged. As the shear rate increased, the rate of formation of entanglements could not keep up with the rate of disruption of the entanglements and resulted in decrement of viscosity with the increase in 
TABLE 2: Miscibility parameters of Isabgol husk and gum katira blends at $298.15^{\circ} \mathrm{K}, 313.15^{\circ} \mathrm{K}$, and $333.15^{\circ} \mathrm{K}$.

\begin{tabular}{|c|c|c|c|c|c|c|c|c|c|}
\hline \multirow{2}{*}{$\begin{array}{l}\text { Mass\% } \\
\text { composition of } \\
\text { Isabgol-gum katira }\end{array}$} & \multicolumn{2}{|c|}{ At $298.15^{\circ} \mathrm{K}$} & \multirow{2}{*}{$\Delta b$} & \multicolumn{2}{|c|}{ At $313.15^{\circ} \mathrm{K}$} & \multirow{2}{*}{$\Delta b$} & \multicolumn{2}{|c|}{ At $333.15^{\circ} \mathrm{K}$} & \multirow{2}{*}{$\Delta b$} \\
\hline & $\begin{array}{c}b 12^{*}, \\
\text { experimental }\end{array}$ & $\begin{array}{c}b 12, \\
\text { theoretical }\end{array}$ & & $\begin{array}{c}b 12, \\
\text { experimental } \\
\end{array}$ & $\begin{array}{c}b 12, \\
\text { theoretical }\end{array}$ & & $\begin{array}{c}b 12, \\
\text { experimental }\end{array}$ & $\begin{array}{c}b 12, \\
\text { theoretical }\end{array}$ & \\
\hline $1: 0$ & - & - & - & - & - & - & - & - & - \\
\hline $1: 1$ & $8.10 \pm 0.1350$ & $6.3 \pm 0.0305$ & 1.8 & $32.41 \pm 0.6368$ & $14.82 \pm 0.5107$ & 17.59 & $28.56 \pm 0.4201$ & $19.43 \pm 0.4968$ & 9.13 \\
\hline $2: 1$ & $48.94 \pm 1.1302$ & $6.3 \pm 0.0305$ & 42.64 & $39.00 \pm 0.5430$ & $14.82 \pm 0.5107$ & 24.18 & $31.21 \pm 0.6179$ & $19.43 \pm 0.4968$ & 11.78 \\
\hline $1: 2$ & $14.00 \pm 0.2709$ & $6.3 \pm 0.0305$ & 7.7 & $26.65 \pm 0.3873$ & $14.82 \pm 0.5107$ & 11.83 & $23.12 \pm 0.3513$ & $19.43 \pm 0.4968$ & 3.69 \\
\hline $1: 0$ & - & - & - & - & - & - & - & - & - \\
\hline
\end{tabular}

"Average of three successive results $(n=3)$ and “ \pm " value is the standard deviation.

TABLE 3: Consistency index $(K)$ and flow index $(n)$ of blends in $1: 1$ mass $\%$ of Isabgol husk and gum katira at $298.15^{\circ} \mathrm{K}, 313.15^{\circ} \mathrm{K}$, and $333.15^{\circ} \mathrm{K}$.

\begin{tabular}{lcccccc}
\hline $\begin{array}{l}\text { \%Composition } \\
\text { (Isabgol husk:gum } \\
\text { katira) }\end{array}$ & $\begin{array}{c}\text { Consistency } \\
\text { index }(K) \\
(\mathrm{mPa} \cdot \mathrm{s})\end{array}$ & Flow index $(n)$ & $\begin{array}{c}298.15^{\circ} \mathrm{K} \\
\text { Consistency } \\
\text { index }(K) \\
(\mathrm{mPa} \cdot \mathrm{s})\end{array}$ & $\begin{array}{c}313.15^{\circ} \mathrm{K} \\
\text { Flow index }(n)\end{array}$ & $\begin{array}{c}\text { Consistency } \\
\text { index }(K) \\
(\mathrm{mPa} \cdot \mathrm{s})\end{array}$ & $\begin{array}{c}\text { Flow index }(n) \\
100: 00\end{array}$ \\
\hline $1.9025 \pm 0.0092$ & $0.7070 \pm 0.0086$ & $1.9063 \pm 0.0422$ & $0.6387 \pm 0.0094$ & $2.2989 \pm 0.0387$ & $0.5818 \pm 0.011$ \\
$75: 25$ & $1.6790 \pm 0.0510$ & $0.5132 \pm 0.0091$ & $1.7098 \pm 0.0342$ & $0.3833 \pm 0.0119$ & $1.8147 \pm 0.1225$ & $0.2747 \pm 0.0074$ \\
$50: 50$ & $1.6846 \pm 0.0510$ & $0.3893 \pm 0.0111$ & $1.6582 \pm 0.0858$ & $0.2771 \pm 0.0145$ & $1.7721 \pm 0.0387$ & $0.2145 \pm 0.0120$ \\
$25: 75$ & $1.5705 \pm 0.0469$ & $0.2635 \pm 0.0097$ & $1.6163 \pm 0.0063$ & $0.1548 \pm 0.0079$ & $1.6922 \pm 0.0145$ & $0.1271 \pm 0.0077$ \\
$00: 100$ & $1.2732 \pm 0.0044$ & $0.6323 \pm 0.0117$ & $1.8864 \pm 0.0489$ & $0.5195 \pm 0.0065$ & $1.9665 \pm 0.0161$ & $0.4995 \pm 0.0059$ \\
\hline
\end{tabular}

"Average of three successive results $(n=3)$ and " \pm " value is the standard deviation.

shear rate. The effect of shear rate was also observed on Isabgol husk dispersion and gum katira dispersion, but it was comparatively more and significant in blends as steep decrement in viscosity of dispersions was created on increment of shear stress.

The flow index $(n)$ and consistency index $(K)$ values obtained from the Power law model ( 9 ) for the blends at 298.15, 313.15, and $333.15^{\circ} \mathrm{K}$ are represented in Table 3. In all the blends, the value of " $n$ " was deviated away from " 1 " ( $n<1 ; n=1$ for Newtonian fluids) representing the shearthinning flow behavior. The values of " $n$ " obtained in all blends were decreased from $0.5132 \pm 0.0091$ to $0.2635 \pm$ 0.0097 as the temperature was increased from $298.15^{\circ} \mathrm{K}$ to $333.15^{\circ} \mathrm{K}$, respectively. But, the consistency index $(K)$ was increased on increasing the temperature. The flow index $(n)$ was decreased from $0.7070 \pm 0.0086$ to $0.2635 \pm 0.0097$ as the ratio of Isabgol in blends was changed from 100 to $25 \%$, respectively, at $298.15^{\circ} \mathrm{K}$. The decrement of flow index $(n)$ on decreasing the Isabgol husk ratio in blends was observed at each temperature of the study and indicated the more profound effect of Isabgol husk on blends consistency. It may be due to a more pronounced shear-thinning flow behavior of the blends at lower husk concentration. This finding was consistent with Chun and Yoo [26], who reported that the " $n$ " values for sweet potato flour dispersions were decreased while increasing the flour concentration. The viscoelastic nature of gum katira was lower than Isabgol husk as flow index (n) of gum katira dispersion was less than Isabgol husk. It has been reported that high temperature, shear, and pressure during extrusion usually lead to the degradation of macromolecular structure of polysaccharides, thereby resulting in a decrease in the molecular weight, and the polysaccharides with high molecular weight and rigid conformation exhibit a more distinct shear-thinning rheological behavior [27-29]. It has also been reported that a decrease in the molecular weight of polysaccharides can lead to the reduction of their viscosity [30]. The considerable changes in flow index $(n)$, apparent viscosity $\left(\eta_{\text {app }}\right)$, and consistency index $(K)$ were analyzed on changing the temperature and concentration of Isabgol husk and gum katira in blends that may be due to conformational change in structure of Isabgol husk and gum katira. On increasing husk strength from 25 to $100 \%$ in blends at $313.15^{\circ} \mathrm{K}$, consistency index $(K)$ was found to be $1.6163 \pm 0.0063$ and $1.9063 \pm 0.0422 \mathrm{mPa} \cdot \mathrm{s}$, respectively, and, at $333.15^{\circ} \mathrm{K}$, the increment in consistency index $(K)$ was observed from $1.6922 \pm 0.0145$ to $2.2989 \pm 0.2989 \mathrm{mPa} \cdot \mathrm{s}$, respectively. Similarly, the apparent viscosity was increased from $1.902 \pm 1.6301 \mathrm{mPa} \cdot \mathrm{s}$ to $20.303 \pm 1.8905 \mathrm{mPa} \cdot \mathrm{s}$ at $313.15^{\circ} \mathrm{K}$ and from $1.1170 \pm 0.9652 \mathrm{mPa} \cdot \mathrm{s}$ to $16.510 \pm 1.0607 \mathrm{mPa} \cdot \mathrm{s}$ at $333.15^{\circ} \mathrm{K}$, respectively. The increment in the values of " $\eta_{(\mathrm{app})}$ " and " $K$ " for the blends at the higher concentration of husk could be attributed to the greater number of junction zones as the polysaccharides are generally known to form junction zones in solution which prevents flow [31]. It is plausible in the present study that the molecules could be reached closer to one another and junction zones could be more readily formed while increasing the husk concentration, which could cause an increase in the " $\eta_{(\text {app })}$ " and " $K$ " values of blends at higher concentrations.

3.5. Effect of Temperature on Activation Energy $\left(E_{\text {act }}\right)$ of Isabgol Husk and Gum Katira Blends. The temperature dependence 
TABLE 4: Plastic viscosity and yield stress data of 1:1 mass\% blends calculated from Casson equation.

\begin{tabular}{lcccccc}
\hline $\begin{array}{l}\text { \%Composition } \\
\text { Isabgol husk:gum } \\
\text { katira) }\end{array}$ & $\begin{array}{c}\text { Plastic } \\
\text { viscosity } \\
(\mathrm{mPa} \cdot \mathrm{s})^{*}\end{array}$ & $\begin{array}{c}\text { Yield stress } \\
\left(\mathrm{N} / \mathrm{m}^{2}\right)\end{array}$ & $\begin{array}{c}\text { Plastic } \\
\text { viscosity } \\
(\mathrm{mPa} \cdot \mathrm{s})\end{array}$ & $\begin{array}{c}\text { Yield stress } \\
\left(\mathrm{N} / \mathrm{m}^{2}\right)\end{array}$ & $\begin{array}{c}313.15^{\circ} \mathrm{K} \\
\begin{array}{c}\text { Plastic } \\
\text { viscosity } \\
(\mathrm{mPa} \cdot \mathrm{s})\end{array}\end{array}$ & $\begin{array}{c}\text { Yield stress } \\
\left(\mathrm{N} / \mathrm{m}^{2}\right)\end{array}$ \\
\hline $100: 00$ & $3.9661 \pm 0.0524$ & $2.464853 \pm 0.0529$ & $4.1064 \pm 0.0098$ & $2.4715 \pm 0.0220$ & $3.8795 \pm 0.0507$ & $2.1034 \pm 0.1813$ \\
$75: 25$ & $2.4214 \pm 0.0748$ & $2.3035 \pm 0.0976$ & $1.8224 \pm 0.0494$ & $2.2210 \pm 0.0314$ & $1.4252 \pm 0.0136$ & $1.7308 \pm 0.0229$ \\
$50: 50$ & $1.8007 \pm 0.0162$ & $2.2164 \pm 0.0090$ & $1.1622 \pm 0.0084$ & $2.0283 \pm 0.1088$ & $1.0341 \pm 0.0481$ & $1.7891 \pm 0.0464$ \\
$25: 75$ & $1.5662 \pm 0.0036$ & $2.1277 \pm 0.270$ & $1.3312 \pm 0.0225$ & $1.8086 \pm 0.0370$ & $1.1841 \pm 0.0671$ & $0.7002 \pm 0.0119$ \\
$00: 100$ & $1.2016 \pm 0.0114$ & $1.4243 \pm 0.0345$ & $1.1368 \pm 0.0094$ & $1.1979 \pm 0.0084$ & $1.8883 \pm 0.0120$ & $2.1008 \pm 0.0495$ \\
\hline
\end{tabular}

"Average of three successive results $(n=3)$ and “ \pm ” value is the standard deviation.

on apparent viscosity $\left(\eta_{\text {app }}\right)$ of polysaccharide dispersions was described by an Arrhenius model (11) [32]. In the present study, the values of $E_{\text {act }}$ and constant $A$ were determined for Isabgol husk, gum katira, and their blends from the correlation analysis of $1 / T$ versus $\ln \eta_{\text {(app) }}$. The activation energy $\left(E_{\text {act }}\right)$ of blends in 1 mass $\%$ dispersion was determined in temperature range from $298.15^{\circ} \mathrm{K}$ to $333.15^{\circ} \mathrm{K}$, respectively. The values of " $E_{\text {act }}$ " for Isabgol and gum katira dispersion were found to be $516.423 \pm 2.0696$ and $149.06 \pm 0.9508 \mathrm{~kJ} / \mathrm{mol}$, respectively. The effect of Isabgol concentrations in blends was also remarkable on activation energy as on increasing the percentage ratio of Isabgol husk in blends in comparison to gum katira such as $25: 75,50: 50$, and $75: 25$, and the values of " $E_{\text {act }}$ " for blends were $88.906 \pm 1.6052,96.047 \pm 0.8662$, and $138.324 \pm 1.0805 \mathrm{~kJ} / \mathrm{mol}$, respectively. The results obtained for " $E_{\text {act }}$ " were found with high correlation coefficients $\left(0.99<r^{2}\right)$, pointing out that the dependence of $\eta_{\text {app } 60 \mathrm{rpm}}$, for the blends, Isabgol husk, and gum katira, on experimental temperature followed the Arrhenius equation. According to Kim and Yoo [33], the trend of decreasing the viscosity at higher temperature can be associated with the increases in the intermolecular distances as a result of thermal expansion with increased temperature [33]. Furthermore, in the present study, on increasing the husk ratio in blends, the activation energy was increased and was considered due to formation of dense polymeric network that required more energy to flow and the movements of chains could have become more vigorous as the temperature was increased. This increment in temperature thereby resulted in the breakdown of some weakly associated interaction, that is, some smaller junction zones with lesser amounts of hydrogen bonds involved. The loss of this part of associations could lead to a decrease in the viscosity of blends, Isabgol husk, and gum katira dispersions.

\subsection{Effect of Temperature and Determination of Plastic Viscos-} ity and Yield Stress. Plastic or "Casson" fluids are fluidizing bodies characterized by a "yield stress" (or yield point) and with slowly decreasing viscosity at higher shear rates. Other liquid-like materials reach a constant viscosity but only after reaching their yield stress; these are called "Bingham fluids." On increasing the shear rate, the viscosity is gradually decreased in Bingham, Casson, and Casson chocolate fluids; these are considered as shear-thinning systems. Structured fluids often do not flow unless they have reached a critical stress level called the "yield stress," below which a material is "fully elastic" and above which the structure of the material breaks and it starts to flow. The plastic viscosity and yield stress obtained by Casson equation (6) are represented in Table 4. It was observed that yield stress was increased from $2.1277 \pm 0.2700$ to $2.3035 \pm 0.0976 \mathrm{~N} / \mathrm{m}^{2}$ at $298.15^{\circ} \mathrm{K}$ when the percentage ratio of Isabgol husk was increased from 25 to $75 \%$, respectively, in blends. The plastic viscosity was also affected by increasing the ratio of Isabgol husk in blends as it was found to be $1.5662 \pm 0.0036,1.8007 \pm 0.0162$, and $2.4214 \pm$ $0.0748 \mathrm{mPa} \cdot \mathrm{s}$ in $25: 75,50: 50$, and $75: 25$ blends of Isabgol and gum katira, respectively, at $298.15^{\circ} \mathrm{K}$. With an increase in gum content, the intermolecular gap in polysaccharides macromolecules of Isabgol husk may increase that may cause decrement in plastic viscosity on higher strength of gum in blends. A simultaneous increase in plastic viscosity and yield stress has been observed in Casson chocolate (7) and Bingham model (8) by increasing Isabgol husk content in blends as shown in Tables 5 and 6 . The change in yield stress is different statistically than plastic viscosity $(P<0.05)$. This can be explained by the fact that, on adding higher concentration of Isabgol husk, the consistency of the blend could not be affected to a greater extent as both of the polysaccharides dispersions were of significant strength in themselves and it resulted in a slight change in plastic viscosity or flow of the blend. But the higher content of husk was intermixed with polymeric network of gum polysaccharide to a greater extent and the newly developed interlinked blend polymer network created a significant change in yield stress. It is well known that the yield value arises mainly from the interactions between the solid particles [34]. It was observed that the plastic viscosity and yield stress determined by all models were decreased in all blends on increasing the temperature from $298.15^{\circ} \mathrm{K}$ to $333.15^{\circ} \mathrm{K}$. But a regular increment in plastic viscosity and yield stress was even analyzed on having higher concentration of Isabgol husk. It can be explained due to remarkable interlinking of gum and husk polysaccharide structure even at higher temperature. In IPC paste analysis, the consistency multiplier as shown in Table 7 was also changed on changing the husk strength and the pattern of decrement was similar to plastic viscosity and yield stress. The sequence of plastic viscosity data of the hydrodispersions at all thermal ranges was Isabgol husk > Isabgol husk-gum katira > gum katira. However, the plastic viscosity data and 
TABLE 5: Plastic viscosity and yield stress data of 1:1 mass\% blends calculated from Casson chocolate equation.

\begin{tabular}{lcccccc}
\hline $\begin{array}{l}\text { \%Composition } \\
\text { Isabgol husk:gum } \\
\text { katira) }\end{array}$ & $\begin{array}{c}\text { Plastic } \\
\text { viscosity } \\
(\mathrm{mPa} \cdot \mathrm{s})^{*}\end{array}$ & $\begin{array}{c}\text { Yield stress } \\
\left(\mathrm{N} / \mathrm{m}^{2}\right)\end{array}$ & $\begin{array}{c}\text { Plastic } \\
\text { viscosity } \\
(\mathrm{mPa} \cdot \mathrm{s})\end{array}$ & $\begin{array}{c}313.15^{\circ} \mathrm{K} \\
\text { Yield stress } \\
\left(\mathrm{N} / \mathrm{m}^{2}\right)\end{array}$ & $\begin{array}{c}\text { Plastic } \\
\text { viscosity } \\
(\mathrm{mPa} \cdot \mathrm{s})\end{array}$ & $\begin{array}{c}333.15^{\circ} \mathrm{K} \\
\text { Yield stress } \\
\left(\mathrm{N} / \mathrm{m}^{2}\right)\end{array}$ \\
\hline $100: 00$ & $3.9692 \pm 0.0459$ & $59.083 \pm 0.5798$ & $3.8682 \pm 0.0579$ & $57.938 \pm 0.7718$ & $3.4452 \pm 0.1557$ & $50.464 \pm 0.6303$ \\
$75: 25$ & $2.7114 \pm 0.0557$ & $54.891 \pm 1.1219$ & $2.4224 \pm 0.0557$ & $49.093 \pm 0.6980$ & $1.3252 \pm 0.0645$ & $42.635 \pm 1.1956$ \\
$50: 50$ & $1.8486 \pm 0.0272$ & $48.277 \pm 0.9902$ & $1.4622 \pm 0.0272$ & $37.286 \pm 0.7415$ & $1.1872 \pm 0.0114$ & $33.214 \pm 0.7813$ \\
$25: 75$ & $1.2497 \pm 0.0224$ & $38.023 \pm 0.3059$ & $1.1312 \pm 0.0224$ & $32.292 \pm 0.8600$ & $1.0841 \pm 0.0325$ & $31.022 \pm 0.6193$ \\
$00: 100$ & $1.5016 \pm 0.0112$ & $19.762 \pm 0.3071$ & $1.1368 \pm 0.0112$ & $21.609 \pm 0.9596$ & $1.1183 \pm 0.0889$ & $13.963 \pm 0.7606$ \\
\hline
\end{tabular}

"Average of three successive results $(n=3)$ and " \pm " value is the standard deviation.

TABLE 6: Plastic viscosity and yield stress data of 1:1 mass\% blends from Bingham equation.

\begin{tabular}{|c|c|c|c|c|c|c|}
\hline \multirow{2}{*}{$\begin{array}{l}\text { \%Blend } \\
\text { composition } \\
\text { (Isabgol husk: gum } \\
\text { katira) }\end{array}$} & \multicolumn{2}{|c|}{$298.15^{\circ} \mathrm{K}$} & \multicolumn{2}{|c|}{$313.15^{\circ} \mathrm{K}$} & \multicolumn{2}{|c|}{$333.15^{\circ} \mathrm{K}$} \\
\hline & $\begin{array}{c}\text { Plastic } \\
\text { viscosity } \\
(\mathrm{mPa} \cdot \mathrm{s})^{*}\end{array}$ & $\begin{array}{l}\text { Yield stress } \\
\left(\mathrm{N} / \mathrm{m}^{2}\right)\end{array}$ & $\begin{array}{l}\text { Plastic } \\
\text { viscosity } \\
(\mathrm{mPa} \cdot \mathrm{s})\end{array}$ & $\begin{array}{l}\text { Yield stress } \\
\left(\mathrm{N} / \mathrm{m}^{2}\right)\end{array}$ & $\begin{array}{l}\text { Plastic viscosity } \\
\quad(\mathrm{mPa} \cdot \mathrm{s})\end{array}$ & $\begin{array}{l}\text { Yield stress } \\
\left(\mathrm{N} / \mathrm{m}^{2}\right)\end{array}$ \\
\hline $100: 00$ & $4.9644 \pm 0.0566$ & $54.249 \pm 0.7823$ & $4.1303 \pm 0.0252$ & $49.61 \pm 0.3671$ & $3.6151 \pm 0.07104$ & $51.42 \pm 0.6080$ \\
\hline $75: 25$ & $3.9867 \pm 0.0812$ & $47.991 \pm 0.5249$ & $3.5824 \pm 0.1096$ & $46.379 \pm 0.6249$ & $3.3013 \pm 0.0605$ & $40.33 \pm 0.8000$ \\
\hline $50: 50$ & $3.7473 \pm 0.1575$ & $44.381 \pm 0.7967$ & $2.9842 \pm 0.0718$ & $33.03 \pm 0.8479$ & $1.8621 \pm 0.0163$ & $30.21 \pm 0.5445$ \\
\hline $25: 75$ & $2.8009 \pm 0.1065$ & $36.024 \pm 1.0205$ & $2.2002 \pm 0.0793$ & $27.39 \pm 0.5631$ & $1.9173 \pm 0.0634$ & $25.06 \pm 0.7350$ \\
\hline $00: 100$ & $2.8747 \pm 0.0688$ & $25.064 \pm 1.030$ & $2.6609 \pm 0.1024$ & $23.62 \pm 0.5337$ & $1.9988 \pm 0.0886$ & $18.78 \pm 0.8113$ \\
\hline
\end{tabular}

*Average of three successive results $(n=3)$ and " \pm " value is the standard deviation.

TABLE 7: Consistency multiplier data of 1:1 mass\% blends calculated from IPC paste analysis.

\begin{tabular}{lccc}
\hline \%Blend composition (Isabgol husk : gum katira) & $\begin{array}{c}298.15^{\circ} \mathrm{K} \\
\text { Consistency multiplier }\end{array}$ & $\begin{array}{c}313.15^{\circ} \mathrm{K} \\
\text { Consistency multiplier }\end{array}$ & $\begin{array}{c}333.15^{\circ} \mathrm{K} \\
\text { Consistency multiplier }\end{array}$ \\
\hline $100: 00$ & $6.2235 \pm 0.0256$ & $5.7790 \pm 0.1023$ & $2.9622 \pm 0.0287$ \\
$75: 25$ & $5.0672 \pm 0.0869$ & $4.6648 \pm 0.1161$ & $3.4512 \pm 0.0511$ \\
$50: 50$ & $4.5448 \pm 0.1164$ & $3.8566 \pm 0.1255$ & $2.5612 \pm 0.0835$ \\
$25: 75$ & $4.0724 \pm 0.0828$ & $2.0024 \pm 0.0597$ & $2.0754 \pm 0.0827$ \\
$00: 00$ & $4.4421 \pm 0.0734$ & $4.5035 \pm 0.0071$ & $3.6218 \pm 0.0116$ \\
\hline
\end{tabular}

"Average of three successive results $(n=3)$ and " \pm " value is the standard deviation.

yield stress data were slightly higher for Bingham model than those obtained from Casson and Casson chocolate equation. The deviation of the fitted parameters for Bingham equation was $<0.05 \%$ when compared to $\sim 1 \%$ of deviation obtained for Casson and Casson chocolate equation.

\section{Conclusion}

The miscibility of Isabgol husk and gum katira blends in equal proportions as well as in higher concentrations of one another was found at studied thermal conditions. The blends and their components such as Isabgol husk and gum katira were found to be pseudoplastic in viscosity behaviour as, on increasing the shear stress, the viscosity was decreased down. The pseudoplastic behaviour was also revealed in acidic and basic media with remarkable results. The significant effect on rheological behaviour was shown by Isabgol husk as on higher concentration of husk; the plastic viscosity and yield stress were increased as analyzed by Bingham, Casson, and Casson chocolate model. The effect of temperature on viscosity was found according to Arrhenius equation, and in blends containing higher concentration of Isabgol husk than gum katira, more energy was required to start the flow. The results of miscibility of Isabgol husk and gum katira blends proved that the blends of these biopolymers may have potential in food and pharmaceutical industries. The pseudoplastic flow pattern in acidic and basic media may also play significant role in blends performance during food processing. In drug delivery systems, these blends may act as modulator for drug release in different environmental conditions of in vitro as well as in vivo studies. Also, applicability of the shearthinning/pseudoplastic behaviour of these blends may also be advantageous for easy flow of lava, ketchup, jellies, gems, nail 
polish, paint, cream, paste, ointment, and varnish and even for some polymeric solutions from the containers.

\section{Conflict of Interests}

The authors of this paper declare that there is no conflict of interests regarding its publication.

\section{References}

[1] G. K. Jan, D. P. Shah, V. D. Prajapati, and V. C. Jain, "Gums and mucilages: versatile excipients for pharmaceutical formulations," Asian Journal of Pharmaceutical Sciences, vol. 4, no. 5, pp. 309-323, 2009.

[2] N. A. Peppas, P. Bures, W. Leobandung, and H. Ichikawa, "Hydrogels in pharmaceutical formulations," European Journal of Pharmaceutics and Biopharmaceutics, vol. 50, no. 1, pp. 27-46, 2000.

[3] L. Dong and A. S. Hoffman, "A novel approach for preparation of $\mathrm{pH}$-sensitive hydrogels for enteric drug delivery," Journal of Controlled Release, vol. 15, no. 2, pp. 141-152, 1991.

[4] R. A. Siegel and B. A. Firestone, "Mechanochemical approaches to self-regulating insulin pump design," Journal of Controlled Release, vol. 11, no. 1-3, pp. 181-192, 1990.

[5] B. Immirzi, M. Malinconico, G. Romano, R. Russo, and G. Santagata, "Biodegradable films of natural polysaccharides blends," Journal of Materials Science Letters, vol. 22, no. 20, pp. 13891392, 2003.

[6] I. Mandala, C. Michon, and B. Launay, "Phase and rheological behaviors of xanthan/amylose and xanthan/starch mixed systems," Carbohydrate Polymers, vol. 58, no. 3, pp. 285-292, 2004.

[7] R. Kulkarni and B. Sa, "Enteric delivery of ketoprofen through functionally modified poly(acrylamide-grafted-xanthan)based $\mathrm{pH}$-sensitive hydrogel beads: preparation, in vitro and in vivo evaluation," Journal of Drug Targeting, vol. 16, no. 2, pp. 167-177, 2008.

[8] S. V. Kumar, D. Sasmal, and S. C. Pal, "Rheological characterization and drug release studies of gum exudates of terminalia catappa linn," AAPS PharmSciTech, vol. 9, no. 3, pp. 885-890, 2008.

[9] R. Paladhi and R. P. Singh, "Ultrasonic and rheological investigations on interacting blend solutions of poly(acrylic acid) with poly(vinyl pyrrolidone) or poly(vinyl alcohol)," European Polymer Journal, vol. 30, no. 2, pp. 251-257, 1994.

[10] R. Paladhi and R. P. Singh, "Miscibility and interaction studies on some aqueous polymer blend solutions by ultrasonic and rheological techniques," Journal of Applied Polymer Science, vol. 51, no. 9, pp. 1559-1565, 1994.

[11] B. Singh, N. Sharma, and N. Chauhan, "Synthesis, characterization and swelling studies of $\mathrm{pH}$ responsive psyllium and methacrylamide based hydrogels for the use in colon specific drug delivery," Carbohydrate Polymers, vol. 69, no. 4, pp. 631643, 2007.

[12] D. J. A. Jenkins, C. W. C. Kendall, V. Vuksan et al., "Soluble fiber intake at a dose approved by the US Food and Drug Administration for a claim of health benefits: serum lipid risk factors for cardiovascular disease assessed in a randomized controlled crossover trial," American Journal of Clinical Nutrition, vol. 75, no. 5, pp. 834-839, 2002.

[13] M. Chavanpatil, P. Jain, S. Chaudhari, R. Shear, and P. Vavia, "Development of sustained release gastroretentive drug delivery system for ofloxacin: in vitro and in vivo evaluation," International Journal of Pharmaceutics, vol. 304, no. 1-2, pp. 178-184, 2005.

[14] M. D. Chavanpatil, P. Jain, S. Chaudhari, R. Shear, and P. R. Vavia, "Novel sustained release, swellable and bioadhesive gastroretentive drug delivery system for ofloxacin," International Journal of Pharmaceutics, vol. 316, no. 1-2, pp. 86-92, 2006.

[15] Wealth of India, vol. 2, CSIR, New Delhi, India, 1962.

[16] K. R. Kirtikar and B. D. Basu, Indian Medicinal Plant, vol. I, 1998.

[17] E. L. Hirst and S. Dunstan, "The structure of karaya gum (Cochlospermum gossypium)," Journal of the Chemical Society, pp. 2332-2337, 1953.

[18] G. O. Aspinall, E. L. Hirst, and M. J. Johnston, "The acidic sugar components of Cochlospermum gossypium gum," Journal of the Chemical Society, pp. 2785-2789, 1962.

[19] Y. P. Singh and R. P. Singh, "Compatibility studies on solutions of polymer blends by viscometric and ultrasonic techniques," European Polymer Journal, vol. 19, no. 6, pp. 535-541, 1983.

[20] M. L. Huggins, "The viscosity of dilute solutions of long-chain molecules. IV. Dependence on concentration," Journal of the American Chemical Society, vol. 64, no. 11, pp. 2716-2718, 1942.

[21] M. D. Kurkuri, A. R. Kulkarni, and T. M. Aminabhavi, "Rheological investigations on the dispersions of sodium alginate and guar gum mixtures at different temperatures," Polymer - Plastics Technology and Engineering, vol. 41, no. 3, pp. 469-488, 2002.

[22] L. Yu, G. Z. DeVay, B. Creek, G. H. Lai, C. T. Simmons, and S. R. Neisen, "Enzymatic modification of psyllium," US Patent 6,248,373.248, 2001.

[23] L. Yu and J. Perret, "Effects of solid-state enzyme treatments on the water-absorbing and gelling properties of psyllium," $L W T$ Food Science and Technology, vol. 36, no. 2, pp. 203-208, 2003.

[24] L. Yu and J. Perret, "Effects of xylanase treatments on gelling and water-uptaking properties of psyllium," Journal of Agricultural and Food Chemistry, vol. 51, no. 2, pp. 492-495, 2003.

[25] X. Pei, Acid modification of psyllium [M.S. thesis], Faculty of the Graduate (School of the University of Maryland, College Park, Md, USA, 2008.

[26] S. Chun and B. Yoo, "Steady and dynamic shear rheological properties of sweet potato flour dispersions," European Food Research and Technology, vol. 223, no. 3, pp. 313-319, 2006.

[27] P. Colonna and C. Mercier, "Macromolecular modifications of manioc starch components by extrusion-cooking with and without lipids," Carbohydrate Polymers, vol. 3, no. 2, pp. 87-108, 1983.

[28] R. M. van den Einde, C. Akkermans, A. J. van der Goot, and R. M. Boom, "Molecular breakdown of corn starch by thermal and mechanical effects," Carbohydrate Polymers, vol. 56, no. 4, pp. 415-422, 2004.

[29] E. R. Morris, A. N. Cutler, S. B. Ross-Murphy, D. A. Rees, and J. Price, "Concentration and shear rate dependence of viscosity in random coil polysaccharide solutions," Carbohydrate Polymers, vol. 1, no. 1, pp. 5-21, 1981.

[30] P. J. Wood, "Cereal $\beta$-glucans in diet and health," Journal of Cereal Science, vol. 46, no. 3, pp. 230-238, 2007.

[31] Y. H. Chang and S. W. Cui, "Steady and dynamic shear rheological properties of extrusion modified fenugreek gum solutions," Food Science and Biotechnology, vol. 20, no. 6, pp. 1663-1668, 2011.

[32] Q. Wang and S. W. Cui, Understanding the Physical Properties of Food Polysaccharides, Taylor \& Francis, Boca Raton, Fla, USA, 2005. 
[33] W. Kim and B. Yoo, "Rheological behaviour of acorn starch dispersions: effects of concentration and temperature," International Journal of Food Science and Technology, vol. 44, no. 3, pp. 503-509, 2009.

[34] V. de Graef, F. Depypere, M. Minnaert, and K. Dewettinck, "Chocolate yield stress as measured by oscillatory rheology," Food Research International, vol. 44, no. 9, pp. 2660-2665, 2011. 

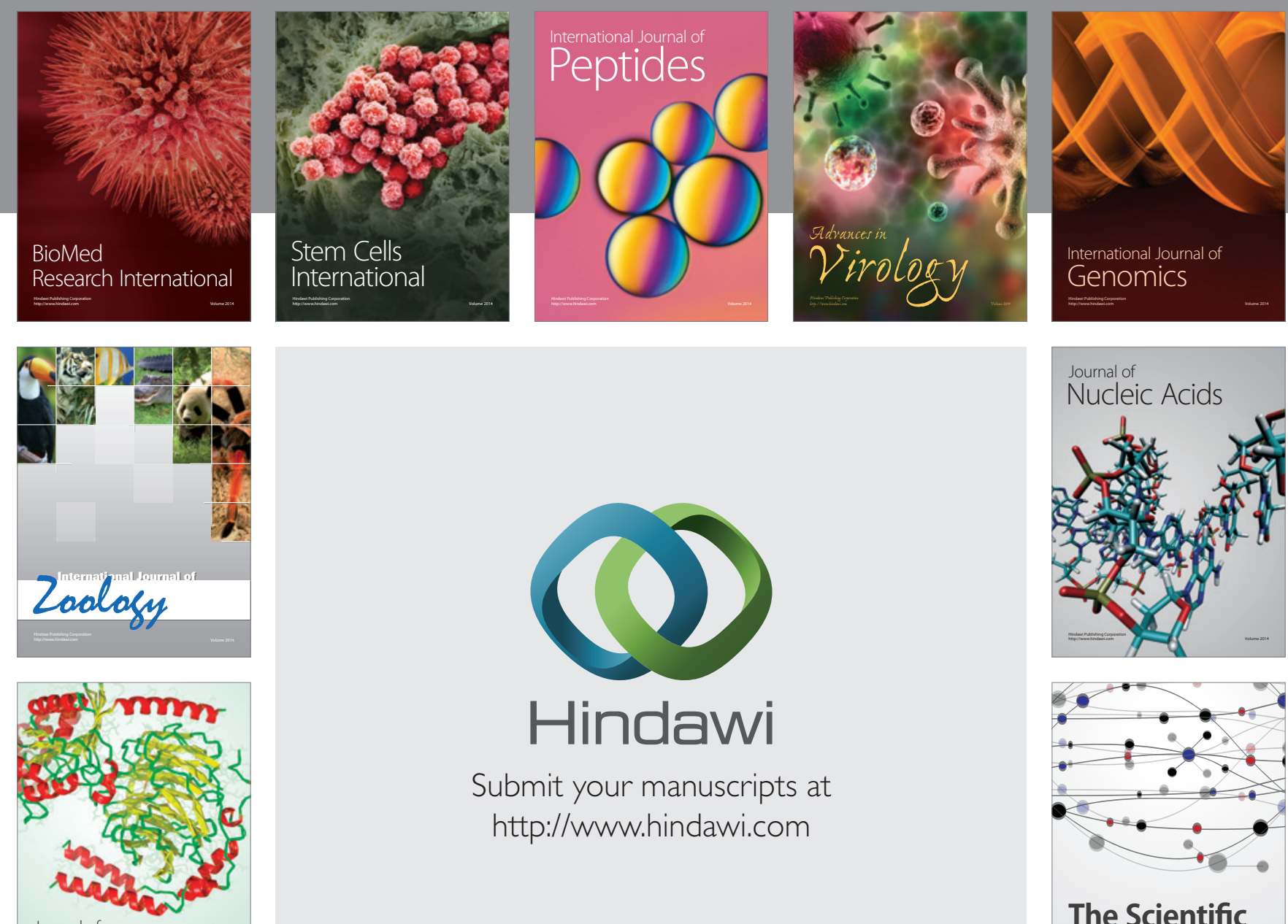

Submit your manuscripts at

http://www.hindawi.com

Journal of
Signal Transduction
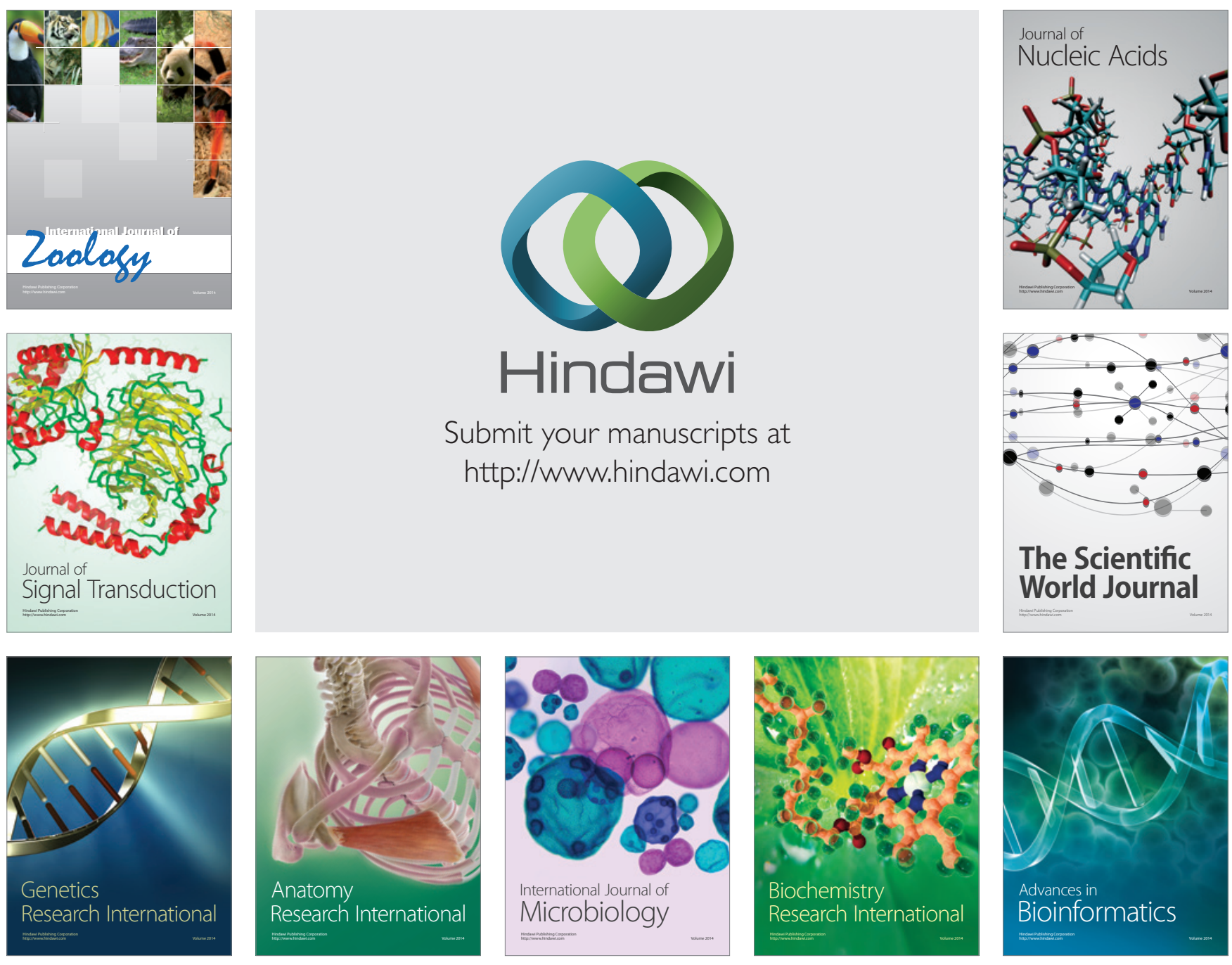

The Scientific World Journal
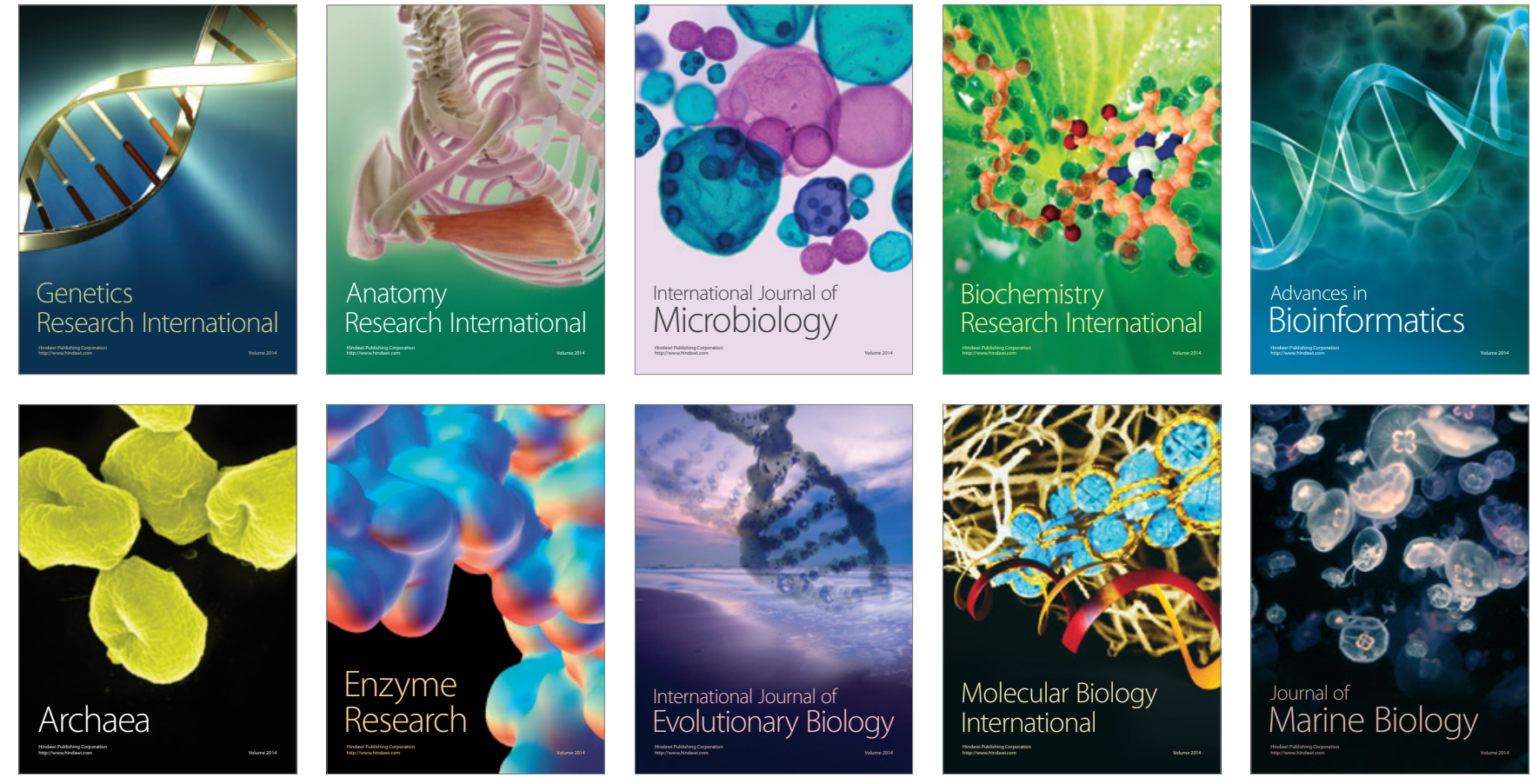